\title{
Distribution of the Common Adder Vipera berus and the Slow Worm Anguis fragils in Silesia, SW Poland
}

\author{
Grzezgorz Kopij
}

Distribution of the Common Adder Vipera berus and the Slow Worm Anguis fragils in Silesia, SW Poland. - Acta Mus. Siles. Sci. Natur., 64: 241-250, 2015.

\begin{abstract}
During the years 2004-2008 the distribution of the Common Adder and the Slow Worm were studied in Silesia through questionnaire directed to forest inspectorates $(n=871) ; 83.8 \%$ of them responded. These data were tested through field work in several randomly selected inspectorates. Both species were found to be widespread in the region, with a few strongholds identified in Sudety Mts. and larger forest complexes. The Common Adder was recorded in $68.5 \%$ of forest districts which responded, while the Slow Worm - in $73.6 \%$ of those districts. Changes in distribution and population trends could not be derived, since no reliable data were available from previous years.
\end{abstract}

Key words: Vipera berus, Anguis fragilis, conservation, atlas, forests, history.

\section{Introduction}

The Common Adder Vipera berus and the Slow Worm Anguis fragils are widespread all over Europe. Together with the Viviparous Lizard Zootoca vivipara, they are the only reptile species which reach the polar circle. The Common Adder has, however, disappeared or declined in many member states of the EU (Arnold, Burton 1978; Juszczyk 1987). Destruction of habitat, fragmentation of populations, and collection for the pet trade are regarded as main factors for this decline. The Slow Worm has also disappeared from some regions in Europe (Arnold, Burton 1978; Juszczyk 1987). Subsequently, both species have been listed as protected (Appendix III) under the Berne Convention and as 'least concern' in the International Union for the Conservation of Nature Red List of Threatened Species. Both species are, however, not included in the Habitat Directive of the EU (92/43/EEC).

In Poland, the Common Adder and Slow Worm were regarded as common and widespread by the year 1970, so much that they were not even provisionally mapped (by recording their presence in particular districts) as was the case for other reptile species (Juszczyk 1987). Subsequent atlas studies conducted during the years 1971-2000 proved that although both species were still widespread all over Poland, they were rare in deforested regions. A slow but continuous decline in some other areas was suggested (Głowaciński, Rafiński 2003). It should be, however, pointed out that the atlas data from 1971-2000 were very incomplete, and since the data were gathered over a very long time-period (30 years!), very little can be concluded on changes in the distribution, population trends or habitats of these species.

Other data on the distribution and abundance of the Common Adder and Slow Worm in Silesia are fragmentary (e.g.: Pax 1925, Simon 1927, Juhnke 1929, Schweisheimer 1933, Werner 1939, Kopij 2003, 2008, 2013) or limited to small areas only, such as Izerskie Mts. (Neuwinger 1908, Hannich 1912), Prudnik district (Schubert 1929), Bytom district (Kotzias 1931), Trzebnica Hills (Berger 1957, Kinal-Szymańska 2002), Strzelińskie Hills (Chlebicki 1988), Korfantów countryside (Kopij 1995), Wrocław surroundings (Ogielska, Konieczny 1999), Książański Landscape Park (Bałuka 2000a), Wałbrzych and surroundings (Bałuka 
2000b; Bałuka, Tritt 2002), Tułowice Forest Ditrict Inspectorate (Jończy, Szambelan 2002), Przemkowski Landscape Park (Rychła et al. 2002), and Upper Silesia (Kowalewski, Profus 2007).

In 2014, the conservation status of both species have been degraded in Poland from strictly protected (Act from 12th October 2011 issued by the Minister of Environment) to partly protected (Act from 8th of October 2014 on the Protection of Animal Species issued by the same Minister). But this decision has not been supported scientifically. Still, little is known on the distribution, even less on changes in the distribution, and almost nothing on prevailing population trends of both species in the whole country or larger parts of it.

I have been, therefore, fully motivated to undertake studies on their distribution in the most industralized region of Poland. The purpose of this study was to generate detailed maps (with a much higher resolution than that employed in atlas studies) of the distribution of both reptile species over relatively short period of time, so as to exclude the effect of temporal changes in the distribution. In the future studies, these maps will constitute reference points to investigate changes in the distribution, habitat selection and population trends in these two species.

\section{Study area}

Silesia, where the presented studies were conducted, is well-defined geographical and historical region in the upper Odra/Oder river drainage system from its sources in Opava Silesia to the mouth of Nysa Łużycka/Lausitzer Neisse. It is divided (Fig. 1) in four provinces: the most eastern Upper Silesia/Oberschlesien (ca. $7000 \mathrm{~km}^{2}$, ca. $30 \%$ forested, ca. 3 mln. people,), further west - Opole Silesia/Oppeln Schlesien $\left(9412 \mathrm{~km}^{2}\right.$, $26.2 \%$ forested, $1.1 \mathrm{mln}$ people in 2002), the largest - Lower Silesia/Niederschlesien $\left(19948 \mathrm{~km}^{2}, 28.3 \%\right.$ forested, $2.9 \mathrm{mln}$ people in 2002) and the most western - southern part of the Lubuskie Province [including the eastern part of the Oberlausitz] (ca. $5000 \mathrm{~km}^{2}$ in Silesia, ca. $50 \%$ forested, ca. $0.6 \mathrm{mln}$ people). The Lower Silesia is further divided into four regions: lowland Wrocław/Breslau in NE, lowland Legnica/Legnietz in NW, mountainous Wałbrzych/Walbrunn in SE and partly lowland partly mountainous Jelenia Góra/Hirschberg Region in SW. Silesia is regarded as the most industrialized region in Poland, especially its eastern part - the Upper Silesia (Fig. 1). Most of Silesian area comprises lowland, with Sudety Mts. and their foothills in the southern part of Lower Silesia. The Silesian surface area is covered with ca. 450 UTM atlas grids, including ca. 100 in Opole Silesia.

\section{Methods}

The distribution of the Common Adder and Slow Worm was studied in the whole province of Silesia during the years 2004-2008 through surveys for data acquisition directed to particular forest districts $(\mathrm{N}=871)$ through forest inspectorates in Silesia (ca. $42000 \mathrm{~km}^{2}$ ), SW Poland, within its boundaries as delineated by Dyrcz et al. (1991), i.e. the former Prussian Schlesien, without this part of Oberlausitz, which is today within Saxony in Germany.

Respondents were requested only whether the Common Adder and the Slow Worm occur currently in particular forest district. Information was obtained from $730(83.8 \%)$ forest districts (57 [89.1\%] forest inspectorates). No information was obtained only from the following forest inspectorates: Kup (15 forest districts), Milicz (18), Wołów (12), Wałbrzych (13), Raszów (11), and Lubsko (19), Kluczbork (13), Rudzieniec (14), Lwówek (15), Gubin (10).

In addition to the main questionnaire directed to forest inspectorates, in Wrocław region, another questionnaire was directed to hunting associations which hold on lease 125 hunting circuits. The questionnaire was addressed to 44 randomly selected circuits: $1,2,8,9,10,11,18,19,24,26,28,30,33,35,38,39,40,41$, $42,43,44,45,46,47,50,51,53,54,58,61,66,67,71,73,78,79,81,83,84,95,101,108,117,118,122,123$. Respondents were requested whether the Common Adder and the Slow Worm occur currently in the particular hunting circuits. Information was obtained from all 44 circuits (100\%).

Data obtained through questionnaire were also tested through field work in randomly selected inspectorates: Miękinia, Oława, Opole, Prószków, Prudnik, and Tułowice. 


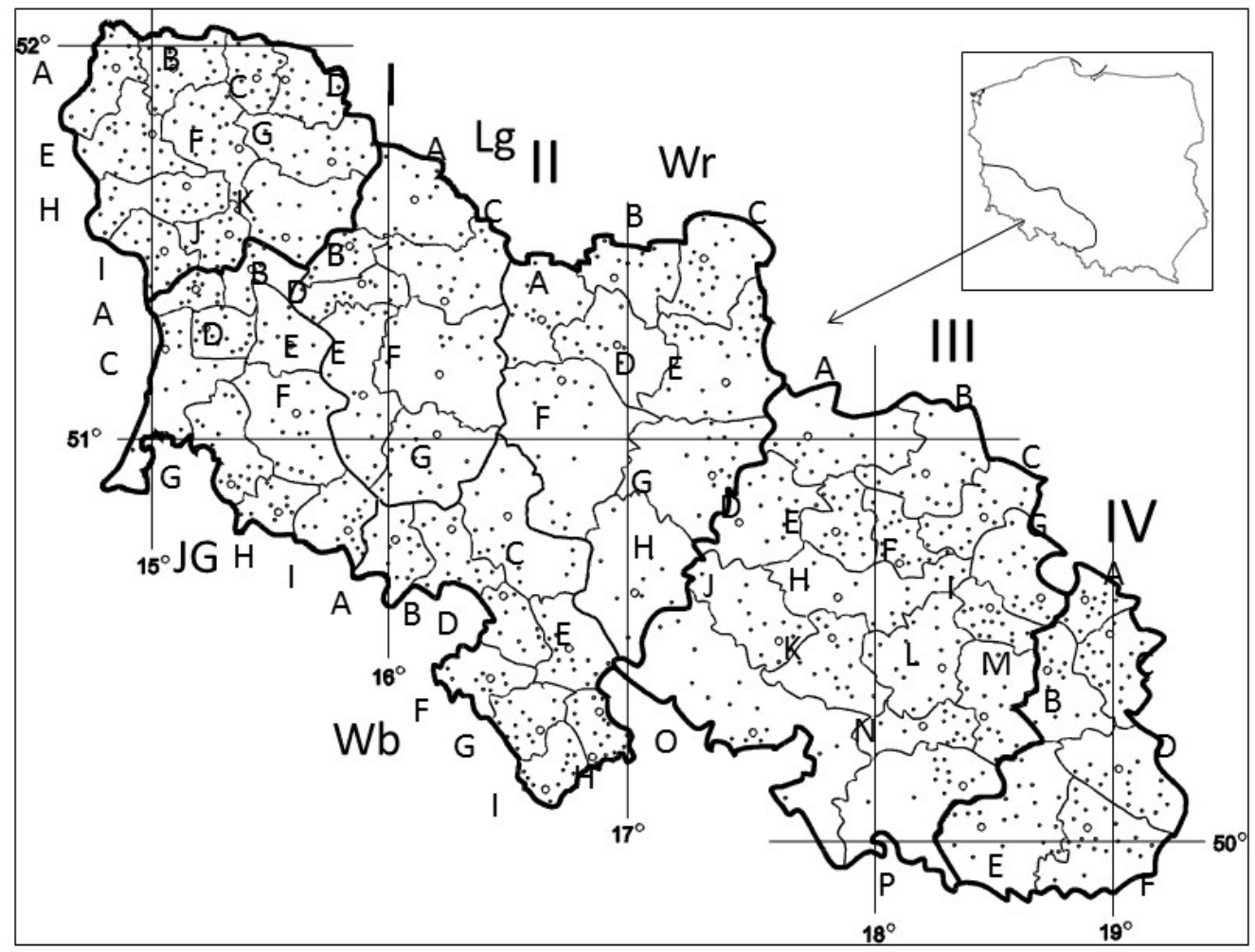

Fig 1: A map of the study area. Small dots: seat of forest district, small open circle: seat of forest district inspectorate, thick lines: province boundaries (I, II, III, IV), medium lines: region boundaries within Lower Silesia province $(\mathrm{Wr}, \mathrm{Wb}, \mathrm{Lg}, \mathrm{ZG})$, thin lines: boundaries of forest district inspectorates (A, B, C...).

I: Southern part of Lubuskie province: A: Gubin, B: Brzózka, C: Zielona Góra, D: Przytok, E: Lubsko, F: Krzystkowice, G: Nowa Sól, H: Lipinki, I: Wymiarki, J: Żagań, K: Szprotawa; II: Lower Silesia: Wr - Wrocław region: A: Wołów, B: Żmigród, C: Milicz, D: Oborniki, E: Oleśnica, F: Miękinia, G: Oława, H: Henryków; Wb - Wałbrzych region: A: Kamienna Góra, B: Wałbrzych, C: Świdnica, D: Jugów, E: Bardo, F: Zdroje, G: Bystrzyca Kłodzka, H: Lądek Zdrój, I: Międzylesie; Lg - Legnica region: A: Głogów, B: Przemków, C: Lubin, D: Chocianów, E: Złotoryja, F: Legnica, G: Jawor; ZG - Zielona Góra region: A: Ruszów, B: Świętoszów, C: Pieńsk, D: Węgliniec, E: Bolesławiec, F: Lwówek, G: Świeradów; H: Szklarska Poręba, I: Śnieżka; III: Opole Silesia: A: Namysłów, B: Kluczbork, C: Olesno, D: Brzeg, E: Kup, F: Turawa, G: Lubliniec, H: Opole, I: Zawadzkie, J: Tułowice, K: Prószków, L: Strzelce Opolskie, M: Rudzieniec, N: Kędzierzyn, O: Prudnik, P: Rudy; IV: Upper Silesia: A: Koszęcin, B: Brynek, C: Świerklaniec, D: Katowice, E: Rybnik, F: Kobiór.

\section{Results and discussion}

In Silesia, only the following reptile species were recorded over the last 400 years: Vipera berus, Natrix natrix, Coronella austriaca, Emys orbicularis, Trachemys scripta elegans, Anguis fragilis, Lacerta agilis, Lacerta viridis, Ootheca vivipara (Schwenckfeld 1603; Weigel 1806; Kaluza 1815; Gloger 1833; Pax 1925; Juszczyk 1987; Głowaciński, Rafiński 2003; Kopij 2014). The first literature record of the Common Adder in Silesia goes back to the beginning of the $17^{\text {th }}$ century. Schwenckfeld (1603) recorded five Adder (Ein Natter, Notter) 'species' occurring in Silesia: $V$. domestica (Ein House Natter), V. nigra (Ein schwarzliche Natter), $V$. purpurea (Ein braune Natter), $V$. cinerea (Ein graue Natter), and $V$. candida (Ein weisse Natter, Hasel Natter). At present, $V$. nigra, $V$. purpurea, and $V$. cinerea are regarded as colour morphotypes only (black, red and grey respectively), while $V$. candida is an albino aberrant morph. $V$. domestica can be viewed today as a kind of ecotype associated with human habitations, or any other snake species adopted to live in man-modified habitat. Schwenckfeld (1603) listed also the Slow Worm under the name Cecilia, (Serpentes caecum, 
Ein Blindschleiche). Gloger (1833) was the first author to list both Common Adder and Slow Worm under the scientific names: Vipera berus and Anguis fragilis respectively.

The first provisional mapping of Common Adder and Slow Worm localities in Poland has been conducted during the years 1971-2000 (Głowaciński, Rafiński 2003). This was a highly opportunistic mapping. The numbers of forest districts, where both the Common Adder and the Slow Worm were recorded during the years 2004-2008, exceeded the number of atlas grids with records of those two species from the years 1971-2000 by the order of magnitude. While during the years 1970-2000, the Slow Worm was recorded only in 10 out of 100 atlas grids in Opole Silesia, during the years 2004-2008 it was recorded there in 131 forest districts (Table 1, Fig. 2). Similarly, the Common Adder was recorded in Opole Silesia over the span of 30 years only in 8 atlas grids, while during five years only (2004-2008), it was recorded in 148 forest districts in this region (Table 1, Fig. 1). Although the atlas grids do not correspond directly with the forest districts, those comparisons illustrate the extend of incompleteness of the data obtained through literature search and survey conducted during the years 1970-2000.

During the years 2004-2008, the Common Adder was recorded in 500 out of 730 forest districts which responded to the questionnaire. This constitutes $68.5 \%$ of all districts in Silesia. The Slow Worm was slightly commoner. It was recorded in 537 such districts $(73.6 \%)$.

Table 1: Common Adder in Silesia (1971-2000: number of atlas grids; 2004-2008: number of forest districts)

\begin{tabular}{|l|ll|ll|}
\hline Province/Region & \multicolumn{2}{c}{ Vipera berus } & \multicolumn{2}{c|}{ Anguis fragilis } \\
& $\mathbf{1 9 7 1 - 2 0 0 0}$ & $\mathbf{2 0 0 4 - 2 0 0 8}$ & \multicolumn{1}{c|}{ 1971-2000 } & $\mathbf{2 0 0 4 - 2 0 0 8}$ \\
\hline Upper Silesia & 15 & 78 & 17 & 71 \\
Opole Silesia & 8 & 148 & 10 & 131 \\
Lower Silesia & 23 & 232 & 25 & 292 \\
Wrocław & $(3)$ & $(31)$ & $(2)$ & $(66)$ \\
Legnica & $(6)$ & $(42)$ & $(2)$ & $(69)$ \\
Wałbrzych & $(5)$ & $(79)$ & $(7)$ & $(74)$ \\
Jelenia Góra & $(9)$ & $(80)$ & $(13)$ & $(83)$ \\
Lubuskie & 1 & 42 & 1 & 43 \\
\hline Total & $\mathbf{4 7}$ & $\mathbf{5 0 0}$ & $\mathbf{5 3}$ & $\mathbf{5 3 7}$ \\
\hline
\end{tabular}

Five core areas of the distribution of the Common Adder population were identified in 2004-2008: Bory Dolnośląskie, Bory Stobrawskie, Bory Niemodlińskie, Sudety Mts. and, unexpectedly, Upper Silesia, the most highly industrialized part of this province. The Upper Sielsia core area was also confirmed during the years 1995-2007 by Kowalewski and Profus (2007). The Common Adder is, however, relativelly uncommon in Lower Silesia (except for Sudety and Bory Dolnośląskie), and southern Opole Silesia (except for Bory Niemodlińskie).

In Saxony, SE Germany, bordering Silesia to the east, the Common Adder is much less common than the Slow Worm. The later species has been recorded almost in all atlas grids in this region, while the former species, only in ca. 50\% of them. In comparison with 1990, a decline in the number of atlas grids with the records of the Common Adder by ca. $20 \%$ was recorded in 2001 (www://alt.nabu-sachsen.de).

During the years 2004-2008, core areas of the distribution of the Slow Worm population in Silesia were identified in Bory Dolnośląskie, Bory Stobrawskie, and Sudety Mts. It is relativelly uncommon in the southern part of the Lubuskie province, Lower Silesia (except for Bory Dolnośląskie and Sudety Mts.), and southern Opole Silesia (except for Bory Niemodlińskie). 


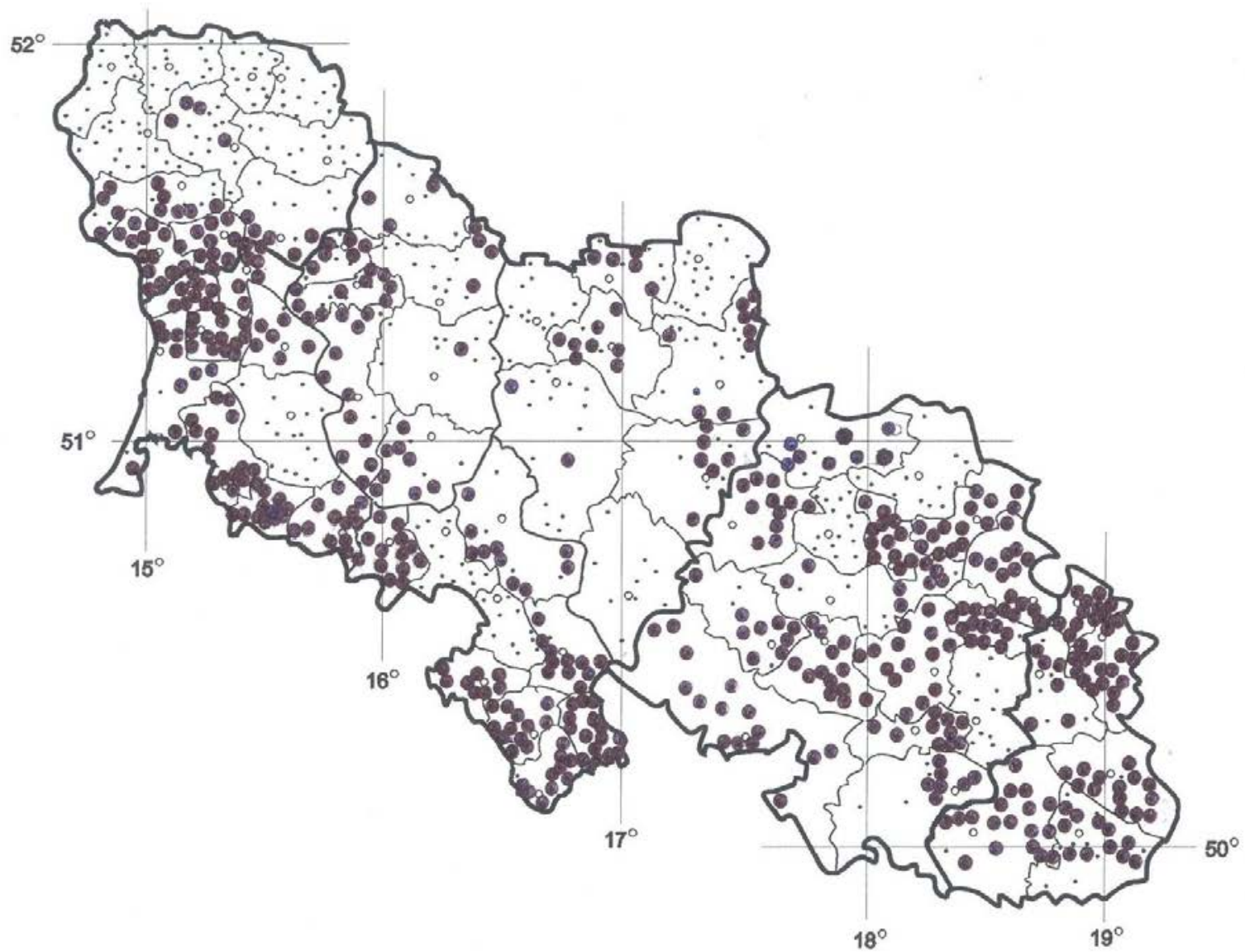

Fig 2: Distribution of the Common Adder in forest districts in Silesia during the years 2004-2008. 


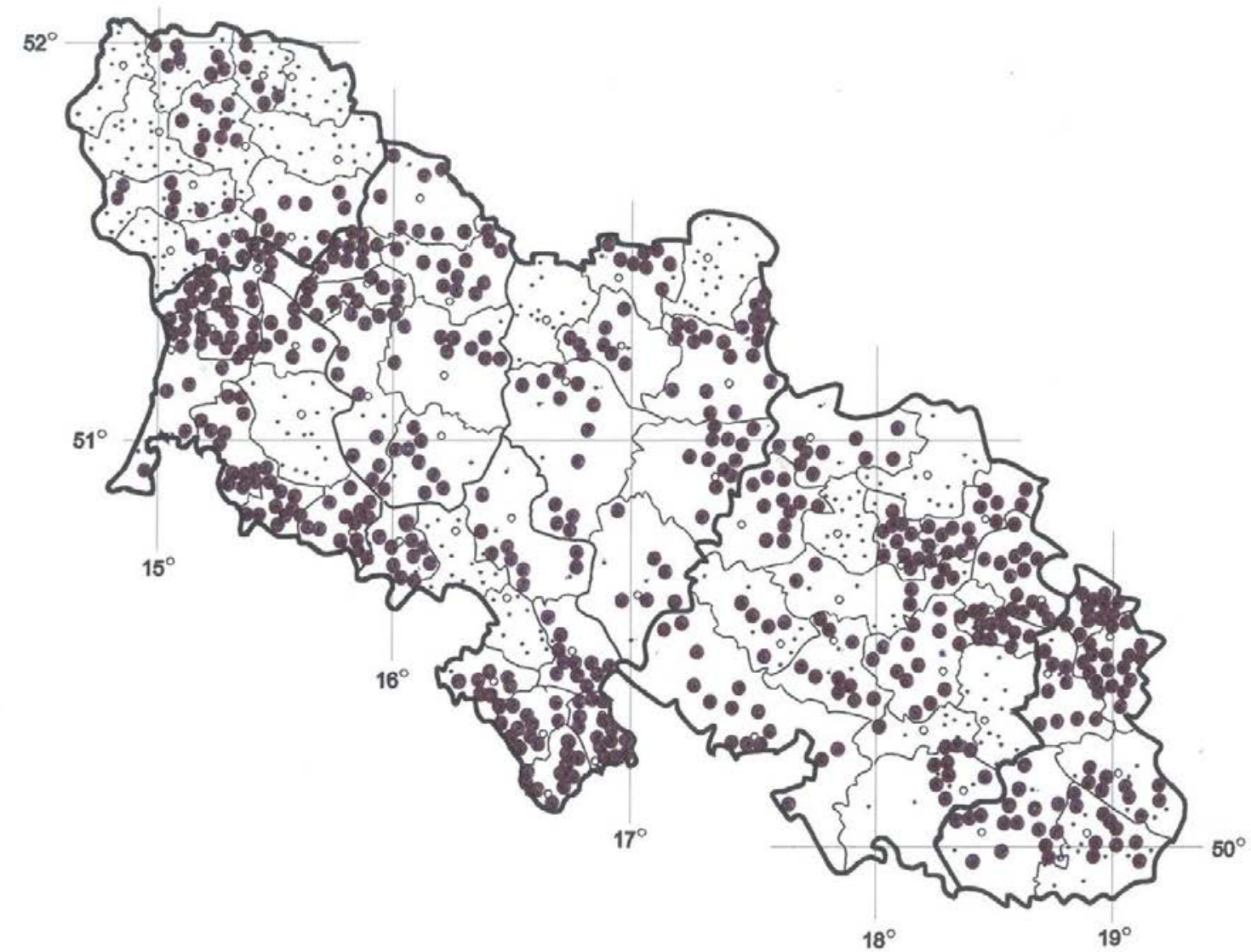

Fig 3: Distribution of the Blind Worm in forest districts in Silesia during the years 2004-2008. 
Out of 45 hunting circuits in Wrocław subregion, both the Common Adder and the Slow Worm occurred in $84.6 \%$ of them. Only in four of these circuits both species were not recorded, while in the remaining both of them were recorded.

The Slow Worm is completly unharmful to people. The Common Adder is the only poisonous snake in Poland, but since 1945 it has not caused any human fatalities in Silesia (Magdalan et al., 2010). Its threat to human life is, threfore, highly exagerated. Out of 28 bite cases recorded there, in $92.3 \%$ only edema of bitten limbs with associated extra vasations were noted and only in $3.8 \%$ cases the edema spread to the trunk; $21.4 \%$ of all these cases were considered severe.

Since the atlas studies from previous years (1970-2000) are very incomplete (at least for Silesia), it is impossible to draw any conclusions on changes in distribution or on prevailing population trends of the Common Adder and Slow Worm. It is, however, hoped that similar distributional studies in Silesia will be conducted in the near future in order to elucidate such changes, if any. This will help to undertake rationale decisions regarding protection of these species in Poland and other EU countries.

Acknowledgements: The following persons are acknowledged for supervising the questionnaire: W. Babiarz, P. Bąk, Z. Bąk, S. Bazan, D. Bełzecki, J. Borysiewicz, M. Brawer, P. Bubniewicz, I. Dworzycki, J. Fidyk, M. Huzarski, S. Jaworski, M. Jędrzejczak, S. Jurecki, B. Kopras, D. Kowalczyk, K. Krakowiak, G. Kubisiak, J. Lenart, S. Mazan, T. Międzyrzecki, R. Miler, J. Mielczarek, J. Moryń, Z. Mosiejczyk, Z. Mrugała, M. Niebrzydowski, T. Norman, Z. Obuchowicz, R. Pabian, W. Piechota, Z. Pleśniarski, J. Podolski, K. Rokoczy, M. Rymarski, W. Skornowicz, G. Skrobek, W. Słowik, B. Stankiewicz, K. Szulc, K. Śpiewak, P. Tetla, A. Walczak, P. Wierzbicki, K. Winduch, M. Witkowski, S. Wojtczak, R. Wrażeń, W. Zaremba, CA. Żmijewski. My thanks are also due to Polish Hunting Association for providing data on the occurrence of reptiles in their hunting circuits.

\section{References}

Arnold E.N. \& Burton J.A. (1978): A field guide to amphibians and reptiles of Britain and Europe. - London, Collins.

Bałuka, B. (2000a): Świat płazów i gadów Książańskiego Parku Krajobrazowego. - In: Zamachowski, W. (ed.). Biologia płazów i gadów - ochrona herpetofauny, p. 6-9. Kraków, Wydawnictwo Naukowe AP w Krakowie.

- (2000b) : Badania nad herpetofauną Wałbrzycha. - In: Zamachowski W. (ed.). Biologia płazów i gadów ochrona herpetofauny; p. 10-12. Kraków, Wydawnictwo Naukowe AP w Krakowie.

Bałuka B. \& Tritt, R. (2002): Płazy - Amphibia Linnaeus, 1758 i gady - Reptilia Laurenti, 1768 na obszarach antropologicznie zmienionego środowiska naturalnego byłego Wałbrzyskiego Zagłębia Węglowego. - In: Zamachowski W. (ed.). Biologia płazów i gadów - ochrona herpetofauny; s. 3-6. Kraków, Wydawnictwo Naukowe AP w Krakowie.

Berger L. (1957): Rzadkie płazy i gady południowej Wielkopolski i Wzgórz Trzebnickich. - Chrońmy Przyrode Ojczysta 13(6): 25-28.

Chlebicki A. (1988): Herpetofauna Wzgórz Strzelińskich na Dolnym Śląsku. - Acta Universitatis Wratislaviensis, Przeglad Zoologiczny 19: 37-52.

Dyrcz A., Grabiński W., Stawarczyk T. \& Witkowski J. (1991): Ptaki Śląska-monografia faunistyczna. - Wrocław, Uniwersytet Wrocławski.

Gloger C.L. (1833): Schlesiens Wirbelthier-Fauna. Ein systematischer Ueberblick der in dieser Provinz verkommenden Säugethieire, Vögel, Amphibien und Fische. Breslau, Verlag von Grafs, Barth und Camp.

Głowaciński Z. \& Rafiński J. (2003): Atlas płazów i gadów Polski. Status - rozmieszczenie - ochrona. Warszawa/Kraków, Biblioteka Monitoringu Środowiska.

Hannich W. (1912): Die Verbreitung der Reptilien im Isergebirge. - Wanderer Iserbeg, 32(9): 134-135.

Jończy R. \& Szambelan P. (2002): Herpetofauna nadleśnictwa Tułowice. - Przyroda Śląska Opolskiego 8: 25-26.

Juhnke K. (1929): Die Kreuzotter im Kreise Wohlau. - Heimatblat Kreis Wohlau, 8(2): 9-15.

Juszczyk W. (1987): Płazy i gady Polski. Vol. 1, 2, 3. - Warszawa, PWN.

Kaluza A. (1815): Systematische Beschreibung der schlesischen Amphibien und Fische. - Breslau. 
Kinal-Szymańska A. (2002): Płazy i gady zachodniej części Wzgórz Trzebnickich. -In : Zamachowski W. (ed.). Biologia płazów i gadów - ochrona herpetofauny; p. 57-59. Kraków, Wydawnictwo Naukowe AP w Krakowie.

Kopij G. (1995): Herpetofauna okolic Korfantowa. - Przyroda Śląska Opolskiego 1: 35-36.

- (2003): Materiały do fauny Śląska Opolskiego. III. - Przyroda Śląska Opolskiego 9: 20-23.

- (2008): Materiały do fauny Śląska Opolskiego. V. - Przyroda Śląska Opolskiego 14: 31-38.

- (2013): Materiały do fauny Śląska Opolskiego. VII. - Przyroda Śląska Opolskiego 19: 36-40.

- (2014): Egzotyczne gatunki kręgowców na Śląsku. - Przyroda Śląska Opolskiego 20: 31-34.

Kotzias H. (1930/31): Die Fische, Lurche und Kriechtiere des Kreises Beuthen. - Mitteilungen des Beuthener Geschichts- und Museumverein 13/14: 173-187.

Kowalewski L. \& Profus P. (2007): Rozmieszczenie, biometria i ekologia żmii zygzakowatej Vipera berus L. na Górnym Śląsku i Wyżynie Częstochowskiej. - Chronmy Przyrode Ojczysta 63: 58-90

Magdalan J., Trocha M., Merwid-Lad A., Sozański T. \& Zawadzki M. (2010): Vipera berus bites in the Region of Southwest Poland - a clinical analysis of 26 cases. - Wilderness Environmental Medicine 21(2): 114-119.

Neuwinger K. (1908): Die Schlangen des Isergebirges. - Mitteilungen des Verein Heimatkunde Bez. Bohm.Aicha und Friedland 2: 81-99.

Ogielska M. \& Konieczny K. (1999): Herpetofauna pradoliny Odry w okolicach Wrocławia: dwa lata po wielkiej powodzi. - Przeglad Zoologiczny 43: 207-214.

Pax F. (1925): Wirbeltierfauna von Schlesien. - Berlin.

Rychła A., Fąckowiak P. \& Szustka K. (2002): Płazy i gady Przemkowskiego Parku Krajobrazowego. Chronmy Przyrode Ojczysta 58(4): 37-61.

Schubert K. (1929): Die Reptilien und Amphibien der Umgegend von Neustadt O/S. - Heimatkalendar des Kreis Neustadt 2: 30-31, 3: 45-47.

Schweisheimer W. (1933): Der Biss der Kreułzotter. Oppelner Heimatkalendar, pp. 122-124.

Schwenckfeld C.A. (1603): Theritropheum Silesiae. - Legnicii, Impenfis Davidis Alberti Bibliopole Vratisl.

Simon P. (1927): Schlingnatter und Kreuzkröte. - Oppelner Heimatblat 2: 25.

Weigel J.A.V. (1806): Faunae Silesiacae prodromus. Verzeichniss der Thiere, die in Schlesien bisher entdeckt und bestimmt sind. - Berlin, Himburgischen Buchhandlung.

Werner R.M. (1939): Sudetenkreutzotter (Pelias sudetica T. Reuss). - Das Aquarium 13(9): 97-101.

Author's address: Grzegorz Kopij, Department of Wildlife Management,Katima Mulilo Campus, University of Namibia Private Bag 1096, Wenela Rd., Katima Mulilo, Namibia;

E-mail: gkopij@unam.na

Deparment of Vertebrate Ecology, Wrocław University of Environmental \& Life Science Kożuchowska 5b, 51-631 Wrocław, Poland; E-mail: grzegorz.kopij@up.wroc.pl

\section{Appendix.}

List of forest districts which responded to the questionnaire. In particular forest districts records of Vipera berus are indicated in brackets with'v'and those of Anguis fragilis with 'a'. Forest inspectorates within each province and region are indicated with the bold case.

SOUTHERN PART OF LUBUSKIE PROVINCE: Szprotawa: Bobrowicy (va), Długie (a), Nowe Miasteczko (a), Leszna Górne (va), Śliwnik (va), Stara Jabłonna, Stara Kopernia (va), Szprotawa (va), Witków (a), Żagań: Baszkowo (va), Cietrzewo (va), Czerna (va), Iłowa (v), Karliki (v), Kowalice (va), Łozy (va), Podlaski (va), Stawy (va), Trzebów (va); Wymiarki: Borowe (va), Jamno (va), Jedliniec (va), Laskowice (va), Lutynka ( va), Piotrów (va), Raszynów (va), Spalona (va), Straszów (va), Wymiarki (va), Zabłocie (va); Lipinki: Grotów (va), Kunice [Żary], Marszów (v), Niwica (v), Nowe Czaple [Bronowice] (v), Olbrachtów (v), Olszyna (va), Olszyniec (a), Sieciejów (va), Strzeszowice (va), Suchleb (va), Trzebiel (va), Zielony Las (va), Złotnik, Żarki; Krzystkowice: Biedrzychowice (a), Bieniów, Bogaczów (a), Guzów (a), Kłępina (a), Kotowice (va), Kosynka (va), Kozła (v), Krzystkowice, Krzywaniec, Lipno, Łęczyce (a), Mokrzyce (va), Tuchola, Żarków; Zielona Góra: Buchałów (a), Czerwińsk, Laski (a), Leśniów, Olcha (a), Przylep, Świdnica (a), Zagórze; Brzózka: Bobrowice (va), Bronków (a), Brzeźnica, Brzózka (a), Kukadło (a), Lubiatów (a), Łąkowa (a), Wełmice, Wężyska (a) 
LOWER SILESIA: W r o c $\nmid$ a w r e g i o n: Żmigród: Borek (va), Chodlewo (v), Gruszeczka, Kaniowo (va), Łąki (a), Niezgoda (va), Olsza (a), Przywsie (a), Radziądz (a), Ujeździec (va), Wilkowo (va); Oleśnica: Bartków (a), Budczyce (va), Dąbrowa (a), Drożęcin (va), Gola Wielka (va), Goszcz [Twardogóra] (va), Grochowo (a), Kątna (va), Ligota Polska (a), Maleszów [Białe Błoto] (a), Nacieszów (va), Ostrowina (va), Sokołowice (a), Sosnówka, Strzelce (a), Szczodre (a), Twardogóra (va), Zalesie [Złotówek] (a), Zamek Myśliwski [Ługi] (a), Zbytowa (va); Oborniki: Cieplice [Bagno], Jary (a), Kramiec [Oborniki] (v), Lipnica (va) Osolin (va), Pęgów (va), Prusice (va); Radecz (va), Rościsławice (va); Oława: Bystrzyca (a), Chrząstawa (va), Dziuplina (va), Janików (va), Jelcz (va), Krawiniec, Kopalina (va), Kotowice (a), Łaziszki [Chwałowice] (va), Miłocice (a), Oleśnica Mała (va), Oława (a), Paczków (a), Łowieckie [OHZ] (va); Miękinia: Chwalimierz, Chwałków (a), Juszczyn (a), Kamionna (va), Kąty Wrocławsie (a), Kiełczyn [Jaźwin] (a), Kobylniki (a) Mokra, Mrozów (a), Ratyń (a), Sulistrowiczki (a), Szczepanów (a), Tąpadło (a), Uliczno [Słupice] (a), Wawrzeńczyce, Wilczków (va); Henryków: Bobolice [Muszkowice] (a), Gościęcin (a), Krzywina [Jagłowa] (a), Niedźwiedź, Sarby (a), Skalice [Henryków] (a), Strachów, Suchowice (a), Witosławice. W a 1 b r z y c h r e g i o n: Bardo: Błotnica (va), Chwalisław (va), Dębowina (va), Grodziszcze (a), Jemna (va). Laski (va), Laskówka (va), Mąkolna (va), Opolnica (va), Tarnowa, Wilcza [Budzów] (v), Wojciechowice (va), Złoty Stok (va); Lądek Zdrój: Bielice (v), Bolesławów (va), Czernica [Stary Gierałtów] (va), Lądek Zdrój (va), Nowa Morawa (a), Młynowiec (va), Orłowiec (v), Nowy Gierałtów (va), Skrzynka (va), Stronie Śląskie (va), Trzebieszowice (va), Wojtówka (va); Międzylesie: Biała Woda (va), Gowrów (va), Idzików (va), Jawornica (va), Jodłów (va), Lesica (va), Nowa Wieś (va), Różanka (va), Smreczyn (va), Szklary (va), Śnieżnik (va); Bystrzyca Kłodzka: Długopole Dolne (va), Kamienna Góra [Pokrzywno] (va), Lasówka (va), Młoty (va), Paszków (va), Piaskowice (va), Poręba (va), Spalona Dolna (v), Spalona Górna (va), Stara Łomnia (va), Szklarka [Gorzanów] (va), Waliszów (va), Wyżki (va), Żelazno (va); „Zdroje” [Szczytna]: Borowniki [Szczytna] (va), Chocieszów (va), Duszniki (va), Kudowa (v), Lewin (va), Orlica (va), Piekiełko [Szczytna] (va), Polanica (va), Wolany (va), Zdrój [Duszniki] (va); Świdnica: Bielawa (va), Bojanowice (va), Gilów (va), Grochotów (va), Jodłownik, Ligota Wielka (a), Lubiechów (va), Lutomia (va), Mrowiny [Żarów], Pierzyce (va), Piława Górna, Piskorzów (a), Witaszów, Zagórze (va), Złoty Las [Lubachów] (v); Kamienna Góra: Błażejów (va), Borówno (va), Chełmsko (va), Dobromyśl (v), Grzędy (va), Jarkowice (va), Klata (va), Krzeszów (va), Lubawka (va), Marciszów (va), Ogorzelec (va), Podlesie (va), Sędzisław (a), Szarocin (va). L e g n i c a r e g i o n: Głogów: Bielawy (v), Dalków (va), Dobromil (va), Duża Wólka (a), Głogówko (a), Gola Wielka (a), Kotla, Obisz (a), Rzeczyca (a), Wilków (va), Zabornia; Lubin: Dąbrówka (a), Koźlice (a), Małomice (a), Nieszczyce (va), Obora (a), Orsk (va), Polkowice (a), Rudna (a), Sieroszowice (a), Sucha Góra, Tymowa (va), Żelazny Most (a); Przemków: Biernatów (va), Cegielnia [Przemków] (va), Kozłów, Nowy Dwór (va), Piotrowice (va), Przemków (va), Szklarki (va), Wilkocin (a); Chocianów: Borówki (a), Chocianów (va), Jakubowice (va), Krzyżowa (va), Nowa Kuźnia (a), Oleszna (va), Parchów (va), Pasternik (va), Trzebień (va), Trzebnice (va), Trzmiel (va), Wierzbowa; Legnica: Dobrzejów (a), Jaroszówka (a), Karczowiska (a), Mierzowice (a), Mołczyn (a), Raszówka I (a), Raszówka II (a), Rogów (a), Szczytniki (va), Zaborów; Złotoryja: Biskupin (va), Jerzmanice (va), Lubiechowa (va), Michałów (a), Modła (va), Nowy Kościół (v), Okmiany (va), Olszanica (va), Podgórki (va), Rokitniki (va), Rzeszówek (va), Wilków, Wojcieszów (va), Wojcieszów Górny (va); Jawor: Chełmice, Dobromierz (va), Kaczorów (va), Kłaczyna (a), Męcinka (va), Muchów (va), Mysłów (v), Myślinów (va), Półwieś (va), Siedmica (va), Żółkiewka. J e l e n i a G ó r a r e g i o n: „Śnieżka” [Kowary]: Borowice, Bukowa (va), Gruszków (va), Janowice (va), Jedlinki [Kowary] (va), Kamienno [Piechowice] (va), Karpacz (va), Karpniki (a), Maciejowa (va), Miłków (va), Podgórzyn (va), Przełęcz (v), Przesieka (v), Skałki (a), Staniszów (a), Strużnica (va); Szklarska Poręba: Górzyniec (va), Jakuszyce (va), Krokusy [Piechowice] (va), Kopaniec (v), Roztoka [Piechowice] (va) Kamienicka Góra [Szklarska Poręba] (va), Kamieńczyk [Szklarska Poręba] (va), Michałowice (va), Orle [Rozdroże] (v), Rozdroże [Chromiec] (va), Roztoka [Piechowice] (va), Ruczaj [Szklarska Poręba] (v), Szklarska Poręba (va), Szronowiec [Szklarska Poręba] (va), Zagórze [Szklarska Poręba] (v), Zieleniec [Szklarska Poręba] (v) ; Świeradów: Czerniance (va), Czocha (a), Izera (v), Kotlina (va), Kwisa [Świeradów] (va), Lasek (va), Lubań (va), Niedźwiedzia Góra [Świeradów] (va), Olszyna (va), Platerówka (va), Przylesie (va) Radostaw (va), Rębiszów (va), Stawy [Młądz] (va), Świecie (va); Pieńsk: Bielawa (va), Białogóry (va), Bierna (va), Bogatynia (va), Dłużyna (va), Grodzieszów (va), Jerzmanki (a), Ostęp (va), Piaseczno (va), Posada, Stojanów (va), Wykroty (va), Zielonka (va); Bolesławiec: Brzezinka (va), Bolesławiec (a), Bukowy Las [Bolesławiec], Daniel [Osiecznica] (va), Dobra (va), Głuszec [Przejęsław] (va), Golenice (a), Jeziory [Brody] (va), Kępnica (va), Osieczów (va), Tomaszów (va); Węgliniec: Bieniec (v), Czerna (va), Czerwona Woda (va), Gaje [Nowogrodziec] (va), Krucze Gniazdo [Węgliniec] (va), Lisek [Tomisław] (va), Ołobok (va), Osiecznica (va), Parowa (va), Stawiska [Stary Węgliniec] (va), Węglowiec [Węgliniec] (va), Zebrzydowa (va); Świętoszów: Dębowiec [Świętoszów] (va), Głębokie [Parowa] (va), Jelenie Rogi (a), Jeziornik [Rudawice] (va), Lubiechów (a), Łaszowa [Przejęsław] (va), Nowoszów (va), Przejęsław (va), Rudawice (va), Sieraków (va), Strachów [Trzebień Mały] (a); Jugów: Bożków (va), Czerwieńczyce (va), Kalenica (va), Nowa Wieś (va), Pogórze (va) Słupiec (va), Ścinawaka (va), Świerki (va), Wojbórz (va), Zdrojowisko (va). 
OPOLE SILESIA: Namysłów: Gola (va), Gręboszów, Komorzno (va), Niwki (a), Podmiejskie (va), Polkowskie (va), Smogorzów, Siemysłów (va), Świty (va), Wierzbica (va), Wołczyn (va), Ziemiełowice (va); Olesno: Boroszów (va), Chudoba (va), Drogi Biskupskie (va), Grodzisko (va), Kramonki (va), Leśna (va), Ligota Turawska (va), Nowy Wachów (va), Pruszków (va), Radawka (va), Siedem Żródeł (va), Sternalice (va), Szumirad (va), Trzebieszyn (va); Brzeg: Barucice (va), Dobrzyń (va), Kurznie (va), Kuźnica Katowska (va), Lubsza (va), Nowy Świat (va), Prędocin (va), Rogalice (va), Roszkowice (va), Rybno (va), Stobrawa (va); Turawa: Bierdzany (va), Bukowo (va), Dąbrówka (v), Dębiniec (va), Grabice (v), Jełowa (va), Kadłub [Zakrzów] (va), Laskowice (va), Marszałki (va), Morcinek (va), Osowiec (va), Rzędów (va), Zagwiździe (va); Opole: Dębska Kuźnia (va), Grodziec (va), Knieja (va), Krasiejów (va), Lipowa (va), Narok (va), Zawada (va); Lubliniec: Bór (va), Brzezinki (va), Ciasna (va), Kokotek (va), Koszwice (va), Lubliniec (va), Lagiewniki [Kośmidrowice] (va), Łopian (va), Ponoszów (va), Rędziny (va) Sieraków (va), Solarnia (va), Wystrzyca [Głowacz] (va), Zborowskie (va); Zawadzkie: Dębie (va), Haraszowskie (va), Jaźwin [Staniszcze Wielkie] (va), Kielcza (va), Kolejka (v), Kolonowskie (va), Krupski Młyn (va), Łaziska (v), Mosty (va), Piotrowina [Pietraszcze] (va), Rytwiny (va), Świerkle (va), Wiercholesie (va); Tułowice: Dębina [Kopice] (a), Głębocko, Gnojna (v), Goszczowice [Jaczowice] (va), Grabin (v), Łambinowice [Wierzbie] (va), Przechód (v), Sosnówka (va), Szydłowiec (va), Św.Hubert [Skarbiszowice] (v), Tułowice (v); Prószków: Dębowiec (va), Chrzelice (va), Jeleni Dwór (v), Kopalina (va), Ochodze (va), Pietna (va), Przysiecz (v), Rogów (v), Rzymkowice (va), Smolarnia (va), Strzeleczki (va), Wybłyszczów (va); Strzelce: Daniec (va); Gąsiorowice (va), Górażdże (va), Kadłub (va), Kalinów (va), Klucze (va), Kłodnica (va), Krępna (va), Łąki Kozielskie (va), Miedziana (va), Otmice (va), Poborzany (va), Spórok [Krasiejów] (va), Zakrzów (va); Kędzierzyn: Blachownia (va), Brzezice [Kędzierzyn], Kotlarnia (va), Niezdrowice (va), Pokrzywnica (va), Rudzieniec (v), Sławięcice (v), Stampnica (v), Stara Kuźnia (va); Prudnik: Biechów (va), Biernatów (va), Buków (va), Dębowiec (va), Kubice (va), Lipowa (va), Markowice (va), Moszczanka (va), Opawica (va), Pokrzywna (va), Ściborzyce (va), Trzebina (va), Wilemowice (va); Rudy Raciborskie: Baborów , Bargłówka (va), Borowiec (va), Kiczowa (va), Kotlarnia, Krasiejów (v), Lubieszów (a), Nędza (va), Ponięcice, Rudy (v), Solarnia, Stanica (va), Szymocice.

UPPER SILESIA: Koszęcin: Dubiele (va), Bronów (va), Brusiek (va), Cieszowa (va), Dąbrowa Górna (va), Dyrdy (va), Kalety (va), Klina (va), Lipowiec (va), Piasek (va), Piłka (va), Trójca [Koszęcin] (va), Zielona (va); Brynek: Bezchlebie (va), Brynek, Górniki, Księży Las, Łabędy (va), Nowa Wieś (va), Pniowiec (va), Potempa, Stolarzowice, Strzybnica (va), Świnowice (va), Tworog (va); Świerklaniec: Cynków (va), Imielów (va), Jędrysek, Kolonia Woźnicka (va), Lubocz (va), Miasteczko Śląskie (va), Mieczysko (va), Mikołeska (va), Nakło (va), Pniowiec (va), Polski Las (va), Świerklaniec (va), Truszczyca (va), Wymysłów (va); Rybnik: Adamowiec (va), Baranowice, Chwałęcice (va), Jankowice [Świerklany] (va), Kłokocin (va), Księżnice (va), Luboszowice (va), Ochojec (va), Oczków [Dębisko Stare] (va), Ornotowice [Orzesze] (va), Syrnia, Szczotki [Przygędy] (va), Wielopole (va), Wodzisław (va), Woszczyce (v), Zacisze (v), Zwonowice (va), Żory (va); Kobiór: Branica (va), Czarków, Czarne Doły, Gostyń (v), Jajosty [Bojszowy], Kobiór (va), Międzyrzecze (va), Mokre (va), Mościska (va), Promnice (va), Pawłowice (a), Radostowice (va), Studzienice (va), Świerczyniec (va), Wyry, (va), Zawada (v), Zagoń (v), Zwaków (v); Katowice: Czułów (va), Górki, Imielin (v), Janów (va), Łędziny (va), Makoszowy (v), Muchowiec (v), Murcki (va), Ochojec, Panewnik (va), Podlesie (va), Reta (va), Śmiłowice (va), Wesoła (v), Zadole (va). 